\title{
Retraction Note to: BP neural network-based detection of soil and water structure in mountainous areas and the mechanism of wearing fatigue in running sports
}

\author{
Shan $X u^{1}$
}

Published online: 11 November 2021

(c) Saudi Society for Geosciences 2021

Retraction Note to: Arabian Journal of Geosciences (2021) 14: 920 https://doi.org/10.1007/s12517-021-07215-y

The Editor-in-Chief and the Publisher have retracted this article because the content of this article is nonsensical. The peer review process was not carried out in accordance with the Publisher's peer review policy. The author has not responded to correspondence regarding this retraction.

The original article can be found online at https://doi.org/10.1007/ s12517-021-07215-y.

Shan $\mathrm{Xu}$

xushan0305@163.com

1 Xi' an Shiyou University, Xi' an 710065, Shaanxi Province,

China 